\title{
Cerebral cysticercosis mimicking subarachnoid hemorrhage: a case report
}

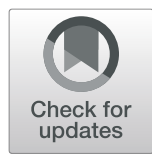

Tao Liu', Tingzhong Wang ${ }^{1}$ Yijun Bao', Jinghua Du² and Yongchang Guan ${ }^{{ }^{*}}$

\begin{abstract}
Background: Dense exudate during the calcification of cerebral cysticercosis in basal subarachnoid space was easy to be misdiagnosed as subarachnoid hemorrhage (SAH); clinical evaluation and MRI can help differentiate SAH from pseudo-SAH.

Case presentation: A case of ventricular expansion accompanied by high-density shadows in cisterna circinata cerebri was taken to the hospital for treatment due to sudden faint. This patient was diagnosed as subarachnoid hemorrhage according to computed tomography (CT) in another hospital. We believe that the high density in cisterna circinata cerebri was misdiagnosed as subarachnoid hemorrhage (SAH) 1 year ago. The main etiology of SAH is aneurysm; non-aneurysmal SAH associated with cerebral cysticercosis is extremely rare. Only 5 patients have been reported.
\end{abstract}

Conclusion: This case indicated that although the specificity of $\mathrm{CT}$ for SAH is very high, the physicians should be aware of rare false positive findings, called pseudo-SAH.

Keywords: Cerebral cysticercosis, Subarachnoid hemorrhage, Computed tomography, Magnetic resonance imaging, Misdiagnosis

\section{Background}

Cerebral cysticercosis is the most common parasitic diseases caused by the larval stage of Taenia solium, involving central nervous system (CNS) [1]. This tapeworm is endemic in most developing countries where pigs are raised, and continues to be one of the most important causes of seizures in the world [2]. Although Taenia solium infection is not endemic in the USA, many neurocysticercosis cases are found in the immigrants from endemic areas of Asia, Africa, Eastern Europe, Mexico, and South America [3]. With increases in immigration from endemic regions, numbers of patients with neurocysticercosis are increasing in the USA. Both adult worm and larvae can infect human, and the larvae gain easily access to brain, eye,

\footnotetext{
*Correspondence: gyc821129@163.com

'Department of Neurosurgery, The Fourth Affiliated Hospital of China Medical University, Shenyang 110032, China

Full list of author information is available at the end of the article
}

and subcutaneous tissue through the small bowel wall to the lymphatics or circulatory system $[4,5]$. It has been found that more than $60 \%$ patients with cerebral cysticercosis can show clinical symptoms after 7 years infection [6]. According to different location of the cysts, cerebral cysticercosis has four main forms: meningeal, parenchymal, ventricular, and mixed lesions. The form of meningeal can be further divided into two subgroups, namely, dorsolateral subarachnoid space and basal subarachnoid space. Cerebral cysticercosis presents protean manifestations including seizures, signs of elevated intracranial pressure (ICP) depending on the number of parasites, different locations, and the degree of host immunologic response to infestation [7].

In this study, we present the case of a man with subarachnoid form of cerebral cysticercosis and his dense exudate of cerebral cysticercosis in basal subarachnoid space was misdiagnosed as subarachnoid hemorrhage. 
Then, we review the pertinent literature on the subject to better this uncommon entity.

\section{Case presentation}

A 49-year-old male with a sudden-onset loss of consciousness, presented to our emergency department (ED), with 1-year history of headache, nausea, vomiting, weakness in the limbs, thirst with desire of drink, hoarseness, and dysphagia.

The patient had similar symptoms 1 year ago, including nausea and vomiting. Head CT were performed in a local hospital (Fig. S1A). Cisterna circinata cerebri with high density image was revealed, and Pandy test in cerebrospinal fluid (CSF) was positive. Then, he was diagnosed as subarachnoid hemorrhage and received relevant symptomatic treatment. But further examination showed that there were no red blood cells in his cerebrospinal fluid, and CTA (Fig. S1B) indicated his intracranial arterial system was normal. Because of indifference and there was no obvious improvement, the patient discharged 3 days later.

After the patient was referred to our hospital, he had a Glasgow Coma Scale score of 15 with retrograde amnesia, there was no fever, pupils were isochoric and normally reactive to light. No obvious abnormality was observed in respiratory, cardiovascular, and gastrointestinal systems. Limb muscle strength was level 4, muscle tension was normal, limbs sophisticated activities were weaken. Physiological reflex was normal, and pathological reflex including meningeal signs was negative (Fig. 1).

The patient had a history of cysticercosis 30 years ago, and the CT value of the high-density shadow near the thalamus and cisternae measured $92 \mathrm{Hu}$ without perihematomal edema, so we considered the high-density shadow as calcification. During the subsequent treatment, there was no significant change in the density (Fig. S2), which also proved our opinion. According to these findings, we thought that the diagnosis was cerebral cysticercosis. Therefore, we performed antibody detection of cysticercosis and found IgG was positive.

At admission, this patient treated with albendazole (15 $\mathrm{mg} / \mathrm{kg} /$ day); meanwhile, short course of dexamethasone $(20 \mathrm{mg} /$ day) along with fatty meals promotes drug absorption [8]. In first 3 days, the patient had a worse headache and dizziness, according to known side effects of albendazole, we reviewed the patient's head CT, and monitored blood counts and liver enzymes but there is nothing unusual.

After regular treatment, the patient had less headache and nausea and no other discomfort; we performed the CT again a month later. CT scan images indicated that the left basal ganglia cystic lesion was significantly smaller and hydrocephalus was slightly smaller than before, there were calcifications in the cystic lesions indicating that the treatment was effective (Fig. S2). Because of financial reasons, at day 30 post-treatment in the hospital, the patient required to be conservative treated at home. Upon evaluation of the patient, we found he was asymptomatic. CSF analysis revealed 10 cells $/ \mathrm{mm}^{3}$ (monocyte 15\%, neutrophils 6\%), $158 \mathrm{mg} / \mathrm{dL}$ protein, and $2.8 \mathrm{mg} / \mathrm{dL}$ glucose. Enzyme-linked immunosorbent assay test on CSF for cerebral cysticercosis was negative.

One month later after discharge, the patient became sluggish, no dizziness, headache, nausea, and vomiting. The patient was referred to hospital again, CT scan
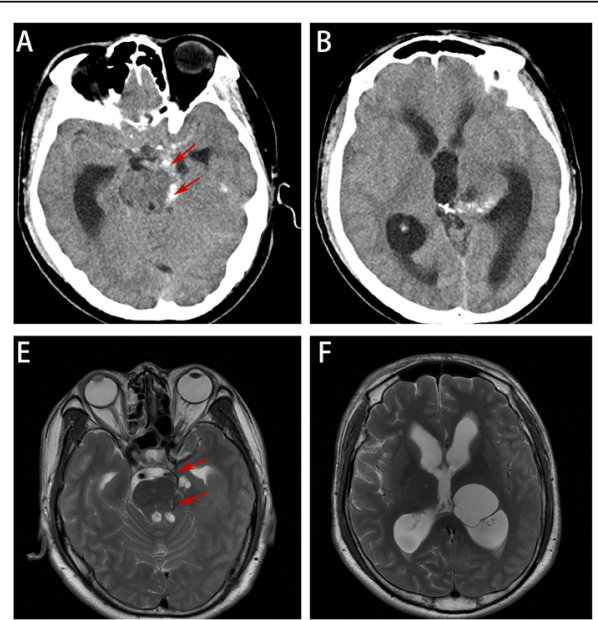
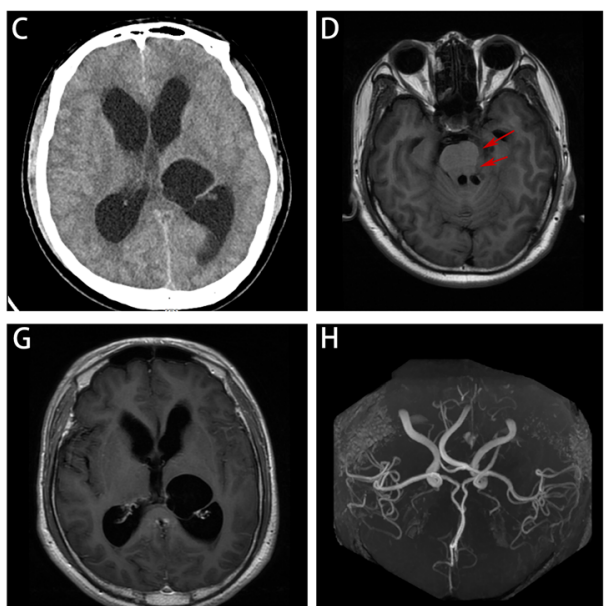

Fig. 1 CT scan images showed high-density shadows in cisterna circinata cerebri were seen (A), and bilateral lateral ventricle and third ventricle dilatation (B). Multiple cystic lesions were seen in the third ventricle, the left basal ganglia region, the left hippocampal region (C). MRI results showed that T1 and T2 presented low signal (D, E). T2 presented high signal in the third ventricle, the left basal ganglia region, the left hippocampal region (F), with no significant enhancement after contrast-enhanced scanning (G). Furthermore, MRA indicated no aneurysms found in intracranial arterial system $(\mathbf{H})$ 
images showed obvious dilation of bilateral ventricle and third ventricle (Fig. S3B), high density shadow was seen in left cerebral cistern and thalamus area (Fig. S3A). At admission, we performed antibody detection of cysticercosis and found IgG was negative. After a consult, the patient had a ventriculoperitoneal shunt placed because of the obstructive hydrocephalus. Postoperatively, cefodizime sodium $(1 \mathrm{~g})$ was administrated intravenously twice a day for 3 days from postoperative day 1 followed by mannitol (50 g) intravenously once a day for 3 days. On the third day after the operation, the signs of hydrocephalus were better than before, and the clinical symptoms were less. No obvious discomfort was observed after drug withdrawal. The patient was discharged on postoperative day 7 , the patient came to the hospital for reexamination 2 week after hospital discharge, and CT showed that supratentorial hydrocephalus was significantly better than before (Fig. S3C, S3D); meanwhile, the patient showed no symptoms of sluggish with a normal gait.

\section{Discussion and conclusions}

Cysticercosis is common in developing countries. Reports from China demonstrate prevalence rates of $0.06 \%$, which may climb to $9.83 \%$ in some provinces. It was estimated that around 0.37 million people with cysticercosis live in China [9]. Meanwhile, the relationship between cerebral cysticercosis and stroke is well established previously. The incidence of stroke in neurocysticercosis varies from 2.0 to $11.8 \%[4,10]$. It has been mostly reported that cerebral cysticercosis is associated with ischemic, hemorrhagic strokes mainly referring to SAH were relatively rare. SAH have been noted in subarachnoid cerebral cysticercosis and have been associated with cerebral aneurysms in some cases [11-15]. The main etiology of SAH is aneurysm, non-aneurysmal $\mathrm{SAH}$ associated with cerebral cysticercosis is extremely rare. Only 5 patients have been reported in Table 1.

Among the 5 included case, the ages ranged from 10 to $39(30.6 \pm 11.8)$. Three patients $(60 \%)$ were female, two patients $(40 \%)$ were male, headache predominated in $5(100 \%)$ and blurred vision in $2(40 \%)$ patients. Other symptoms mainly were movement disorder, nausea, and vomiting. Most patients presented with epileptic seizures $[18,19]$, but our case did not. A review showed that over $50 \%$ of patients with subarachnoid cerebral cysticercosis have imaging evidence of vasculitis [20]. But in our patient, no one finding in neuro-imaging studies was the presence of inflammatory aneurysm. Observation to be seen clearly is that patients with non-aneurysmal SAH associated with cerebral cysticercosis mainly predominates in younger adults having fewer classic cardiovascular risk factors compared to patients with stroke non-associated with cerebral cysticercosis. In clinical practice, aneurysms are considered first in young patients with subarachnoid hemorrhage. That is

Table 1 Non-aneurysmal SAH caused by cerebral cysticercosis

\begin{tabular}{|c|c|c|c|c|c|c|}
\hline Report & $\begin{array}{l}\text { Sex/ } \\
\text { age }\end{array}$ & Clinical symptoms & Imaging finding & CSF analysis & Medication & Outcome \\
\hline $\begin{array}{l}\text { 1. Sawhney et al. } \\
1998 \text { [16] }\end{array}$ & $\begin{array}{l}M / \\
10 y\end{array}$ & Headache, nausea, vomiting, and partial seizures & $\begin{array}{l}\text { Left parietal SAH } \\
\text { Multiple cysts }\end{array}$ & NA & $\begin{array}{l}\text { Albendazole } \\
\text { steroids }\end{array}$ & $\begin{array}{l}\text { No } \\
\text { improvement }\end{array}$ \\
\hline $\begin{array}{l}\text { 2. Tellez-Zenteno } \\
\text { et al. } 2003 \text { [17] }\end{array}$ & $\begin{array}{l}F / \\
32 y\end{array}$ & $\begin{array}{l}\text { Headache, dysarthria, hemiparesis, } \\
\text { psychomotoragitation }\end{array}$ & $\mathrm{SAH}$ & $\begin{array}{l}\text { WBC: } 3 / \mathrm{ml} \\
\text { Glucose: } 55 \mathrm{mg} / \mathrm{dL} \\
\text { Proteins: } 33 \mathrm{mg} / \mathrm{dL}\end{array}$ & $\begin{array}{l}\text { Albendazole } \\
\text { steroids }\end{array}$ & Improvement \\
\hline $\begin{array}{l}\text { 3. Tellez-Zenteno } \\
\text { et al. } 2003 \text { [17] }\end{array}$ & $\begin{array}{l}M / \\
34 y\end{array}$ & $\begin{array}{l}\text { Headache, nausea, vomiting, diplopia, gait } \\
\text { disorder, psychomotor agitation, CNS } \\
\text { impairment }\end{array}$ & $\mathrm{SAH}$ & $\begin{array}{l}\text { WBC: } 107 / \mathrm{ml} \\
\text { (97\%L) } \\
\text { Glucose: } 19 \mathrm{mg} / \mathrm{dL} \\
\text { Proteins: } 695 \mathrm{mg} / \\
\mathrm{dL}\end{array}$ & $\begin{array}{l}\text { Albendazole } \\
\text { steroids }\end{array}$ & Improvement \\
\hline $\begin{array}{l}\text { 4. Viola et al. } \\
2011[12]\end{array}$ & $\begin{array}{l}\text { F/ } \\
39 y\end{array}$ & severe headache & $\begin{array}{l}\text { SAH around the } \\
\text { left Sylvian fissure }\end{array}$ & $\begin{array}{l}\text { RBC: 18/ml (78\% L, } \\
5 \% \text { E) WBC: } 20 / \mathrm{ml} \\
\text { Glucose: } 88 \mathrm{mg} / \mathrm{dL} \\
\text { protein: } 28 \mathrm{mg} / \mathrm{dL}\end{array}$ & $\begin{array}{l}\text { Dexamethasone } \\
\text { Albendazole }\end{array}$ & $\begin{array}{l}\text { Fully } \\
\text { recovered }\end{array}$ \\
\hline 5. Cardenas et al. & $\begin{array}{l}F / \\
38 y\end{array}$ & $\begin{array}{l}\text { headache ,vomiting, blurred vision. } \\
\text { Meningeal signs and papilledema }\end{array}$ & $\begin{array}{l}\text { SAH } \\
\text { Hydrocephalus } \\
\text { Cysts }\end{array}$ & $\begin{array}{l}\text { WBC: } 147 / \mathrm{ml} \\
\text { (86\%L) } \\
\text { Glucose: } 1 \mathrm{mg} / \mathrm{dL} \\
\text { Proteins: } 222 \mathrm{mg} / \\
\mathrm{dL}\end{array}$ & $\begin{array}{l}\text { Prednisone } \\
\text { albendazole }\end{array}$ & Improvement \\
\hline 6. This study & $\begin{array}{l}M / \\
49 y\end{array}$ & $\begin{array}{l}\text { Headache, nausea, vomiting, weakness in the } \\
\text { limb, hoarseness, dysphagia }\end{array}$ & $\begin{array}{l}\text { Hydrocephalus } \\
\text { Cysts }\end{array}$ & $\begin{array}{l}\text { WBC: } 592 / \mathrm{ml} \\
(67 \% \mathrm{~L}) \\
\text { RBC: } 0 / \mathrm{ml} \\
\text { Glucose: } 30 \mathrm{mg} / \mathrm{dL} \\
\text { Proteins: } 178 \mathrm{mg} / \\
\mathrm{dL}\end{array}$ & $\begin{array}{l}\text { Dexamethasone } \\
\text { Albendazole }\end{array}$ & Improvement \\
\hline
\end{tabular}


indisputable. Because of aneurysmal SAH is a subtype of nontraumatic cerebrovascular disease, which account for $3 \%$ to $5 \%$ of strokes and approximately $85 \%$ of the subarachnoid hemorrhage [21].

As described previously, in the early stage of cerebral cysticercosis, a large number of larvas enter the systemic circulation of host, causing widespread infection of brain tissue along with high fever, headache, and increased intracranial pressure. Nevertheless, at this time, the brain CT lack of typical imaging changes. As we all know, two types of cysts are inclined to develop in the brain tissue: cysticercus cellulosae and cysticercus racemosus.

Cysticercus racemosus, varying in size from $4-12 \mathrm{~cm}$, tends to grow in the basal subarachnoid spaces and induce inflammatory comprising chronic meningitis. The pathogenesis of inflammatory in neurocysticercosis is not clear. Cysts will shrink in 2-5 years and form calcium deposits which could block third ventricle, the fourth ventricle, and midbrain aqueduct causing hydrocephalus. Cysts in basal subarachnoid space produce dense exudate and eventually form calcification. The density of dense exudate in the intermediate stage is lower than that of calcification, but higher than that of normal brain tissue and cerebrospinal fluid. The authors think that it is likely to be close to the density of acute hemorrhage. Because these exudates are in subarachnoid space, they are likely to be misdiagnosed as subarachnoid hemorrhage.

Strict inclusion criteria were used in the literature review, those did not report sufficient information to categorize them as aneurysmal or non-aneurysmal would be excluded. The literatures indicated that the nonaneurysmal SAH in these five cases was caused by cerebral cysticercosis [12, 14, 16, 17]. Magnetic resonance imaging (MRI) or cerebral angiograms did not show any evidence of aneurysms or vascular malformations. So, we classify them as non-aneurysmal. All cases of SAH were confirmed by $\mathrm{CT}$, the misdiagnosis experience of our case gave us a reflection on whether there were misdiagnoses of SAH in the above five cases. Then, we turned our attention to CSF analysis, CSF examination is a reliable auxiliary method for the diagnosis of SAH, especially for suspected $\mathrm{SAH}$, but only a case showed the number of red blood cells in the CSF increased [12]; information of other cases about red blood cells was not available. Therefore, we believe that the four cases of SAH were suspicious $[14,16,17]$ and more evidence is needed to further confirm.

There may be several reasons for the misdiagnosis: Firstly, the patient is young without cardiovascular risk factors, accompanied by headache, nausea, and vomiting. Combined with the imaging findings of the patient, it is easy to be confused with aneurysmal SAH. Second, when the larva gain easily access to brain, the density of dense exudate in the intermediate stage is lower than that of calcification, but higher than that of normal brain tissue and cerebrospinal fluid; there might be meningitis in initial stage, for example, Pandy test in CSF was positive, confirmatory evidence for cerebral cysticercosis is difficult to find. Finally, comprehensive analysis ability of physician is low, and the medical history is not careful enough to obtain; this patient had a history of cysticercosis 30 years ago, there is no relevant description of medical history in the patient's medical record.

In conclusion, cerebral cysticercosis is an important cause of neurological diseases that spread in endemic areas. The presentation of the disease is pleomorphic and requires a combination of clinical evaluation, imaging, and laboratory investigation. Furthermore, patients with cysticercosis must be systematically treated to avoid recurrence.

\section{Abbreviations}

SAH: Subarachnoid hemorrhage; CT: Computed tomography; MRI: Magnetic resonance imaging; CNS: Central nervous system; ICP: Intracranial pressure; ED: Emergency department; CSF: Cerebrospinal fluid

\section{Supplementary Information}

The online version contains supplementary material available at https://doi. org/10.1186/s41016-021-00258-w.

Additional file 1. Fig. S1. Radiologic images obtained by CT scan one year ago. Fig. S2. Radiologic images obtained by CT scan at day-30 posttreatment. Fig. S3. Radiologic images obtained by CT scan at day-60 (A, B) and day-74 post-treatment.

\section{Acknowledgements}

We thank the participants for their involvement in and support of the study.

\section{Authors' contributions}

$T L$ and $Y G$ designed the study. $T L$ and J D collected the reference. $T L, T$ $W, Y B$, and $Y G$ contributed to the writing of the manuscript. The author(s) read and approved the final manuscript.

\section{Funding}

This study was funded by the Science and Technology Project of Liaoning Province (2019JH8, 10300066, 2020-MS-147).

\section{Availability of data and materials}

Data sharing is not applicable to this article as no datasets were generated or analyzed during the current study.

\section{Declarations}

Ethics approval and consent to participate Not applicable

\section{Consent for publication}

Written informed consent for publication of their clinical details and clinical images was obtained from the patient.

\section{Competing interests}

Tao Liu, Tingzhong Wang, Yijun Bao, Jinghua Du, and Yongchang Guan have no potential conflicts of interest that might be relevant to the contents of this manuscript. 


\section{Author details}

'Department of Neurosurgery, The Fourth Affiliated Hospital of China Medical University, Shenyang 110032, China. ${ }^{2}$ Department of Neurology, The Fourth Affiliated Hospital of China Medical University, Shenyang 110032, China.

Received: 6 May 2021 Accepted: 5 August 2021

Published online: 02 September 2021

\section{References}

1. Garcia HH, Del Brutto OH, Nash TE, White AC Jr, Tsang VC, Gilman RH. New concepts in the diagnosis and management of neurocysticercosis (Taenia solium). Am J Trop Med Hyg. 2005;72(1):3-9. https://doi.org/10.4269/ajtmh.2 005.72.3.

2. Garcia HH, Nash TE, Del Brutto $\mathrm{OH}$. Clinical symptoms, diagnosis, and treatment of neurocysticercosis. Lancet Neurol. 2014;13(12):1202-15. https:// doi.org/10.1016/s1474-4422(14)70094-8.

3. Sorvillo FJ, DeGiorgio C, Waterman SH. Deaths from cysticercosis, United States. Emerg Infect Dis. 2007;13(2):230-5. https://doi.org/10.3201/eid1302. 060527

4. Sotelo J, Guerrero V, Rubio F. Neurocysticercosis: a new classification based on active and inactive forms. A study of 753 cases. Arch Intern Med. 1985; 145(3):442-5. https://doi.org/10.1001/archinte.1985.00360030074016.

5. Hotez PJ, Brindley PJ, Bethony JM, King CH, Pearce EJ, Jacobson J. Helminth infections: the great neglected tropical diseases. J Clin Invest. 2008;118(4): 1311-21. https://doi.org/10.1172/jci34261.

6. Christianto BL, Concezio DR, Jens H. Parasitic infections of CNS: Springer: Neurosurgery; 2010.

7. Garcia HH, Del Brutto $\mathrm{OH}$. Neurocysticercosis: updated concepts about an old disease. Lancet Neurol. 2005;4(10):653-61. https://doi.org/10.1016/s14 74-4422(05)70194-0

8. White AC Jr, Coyle CM, Rajshekhar V, Singh G, Hauser WA, Mohanty A, et al. Diagnosis and treatment of neurocysticercosis: 2017 Clinical Practice Guidelines by the Infectious Diseases Society of America (IDSA) and the American Society of Tropical Medicine and Hygiene (ASTMH). Clin Infect Dis. 2018;66(8):e49-75. https://doi.org/10.1093/cid/cix1084.

9. Ying-dan C, Chang-hai Z, Hui-hui Z, Ji-lei H, Lei D, Tin-jun Z, et al. National survey on the current status of important human parasitic diseases in China in 2015. Chin J Parasitol Parasit Dis. 2020;38(1):5-12. https://doi.org/10.1214 0/j.issn.1000-7423.2020.01.002.

10. Del Brutto $\mathrm{OH}$. Cysticercosis and cerebrovascular disease: a review. J Neurol Neurosurg Psychiatry. 1992;55(4):252-4. https://doi.org/10.1136/jnnp.55.4.2 52.

11. Kim IY, Kim TS, Lee JH, Lee MC, Lee JK, Jung S. Inflammatory aneurysm due to neurocysticercosis. J Clin Neurosci. 2005;12(5):585-8. https://doi.org/10.1 016/j.jocn.2004.07.018.

12. Viola GM, White AC Jr, Serpa JA. Hemorrhagic cerebrovascular events and neurocysticercosis: a case report and review of the literature. Am J Trop Med Hyg. 2011;84(3):402-5. https://doi.org/10.4269/ajtmh.2011.10-0429.

13. Agapejev S, Parra-Marinello JL, Bazan R, Ueda AK, Zanini MA. Aneurysm and neurocysticercosis: casual or causal relationship? Case report and review of the literature. Case Rep Med. 2011;2011:782496-4. https://doi.org/10.1155/2 $011 / 782496$

14. Cárdenas G, Guevara-Silva E, Fleury A, Sciutto E, Luis Soto-Hernández J. Subarachnoid hemorrhage in neurocysticercosis: a direct or serendipitous association? Neurologist. 2012;18(5):324-8. https://doi.org/10.1097/NRL. Ob013e31826754fd.

15. Arauz A, Ruiz-Navarro F, Silos H, Vargas-González JC, Arguelles-Morales N, Reyes $\mathrm{M}$, et al. Concurrent asymptomatic inflammatory aneurysm and ischemic stroke due to cysticercal arteritis. Clin Neurol Neurosurg. 2013; 115(12):2540-2. https://doi.org/10.1016/j.clineuro.2013.10.001.

16. Sawhney IM, Singh G, Lekhra OP, Mathuriya SN, Parihar PS, Prabhakar S. Uncommon presentations of neurocysticercosis. J Neurol Sci. 1998;154(1): 94-100. https://doi.org/10.1016/s0022-510x(97)00206-2.

17. Tellez-Zenteno JF, Negrete-Pulido O, Cantú C, Márquez C, Vega-Boada F, García RG. Hemorrhagic stroke associated to neurocysticercosis. Neurologia. 2003;18(5):272-5.

18. Hong Van P, Quang Thieu N, Ba Loi C, Minh Xuan N, Quang HH. Cerebral cysticercosis presenting with recurrent epileptic seizures. Cureus. 2020;12(5): e8153. https://doi.org/10.7759/cureus.8153.
19. Bock M, Garcia HH, Chin-Hong P, Baxi SM. Under seize: neurocysticercosis in an immigrant woman and review of a growing neglected disease. BMJ Case Rep. 2015;2015:bcr2015212839. https://doi.org/10.1136/bcr-2015-212839.

20. Meregildo ED. Multiple neurocysticercosis and aneurismal subarachnoid hemorrhage: case presentation and systematic literature review. Infez Med. 2020;28(2):268-72

21. Lovelock CE, Rinkel GJ, Rothwell PM. Time trends in outcome of subarachnoid hemorrhage: population-based study and systematic review. Neurology. 2010;74(19):1494-501. https://doi.org/10.1212/WNL.0b013e3181 dd42b3.

Ready to submit your research? Choose BMC and benefit from:

- fast, convenient online submission

- thorough peer review by experienced researchers in your field

- rapid publication on acceptance

- support for research data, including large and complex data types

- gold Open Access which fosters wider collaboration and increased citations

- maximum visibility for your research: over $100 \mathrm{M}$ website views per year

At $\mathrm{BMC}$, research is always in progress.

Learn more biomedcentral.com/submissions 